\title{
Optimizing Opportunities for Sustainable Development through Organic Agriculture in Nigeria
}

\author{
A. J. Augustine, ${ }^{1} *$ G. E. Jokthan, ${ }^{1}$ I. C. Zarafi ${ }^{2}$ and G. M. Bivan ${ }^{3}$ \\ ${ }^{I}$ School of Science and Technology, National Open University of Nigeria, Lagos, Nigeria \\ ${ }^{2}$ National Open University of Nigeria, Abuja, Nigeria \\ ${ }^{3}$ Department of Agricultural Economics and Extension, Ahmadu Bello University, Zaria, Nigeria
}

\begin{abstract}
Organic agriculture is a holistic production management system that avoids the use of synthetic fertilizers, pesticides and genetically modified organisms, minimizing pollution of air, soil and water, and optimizing the health and productivity of interdependent communities of plants, animals and people. To meet these objectives, farmers need to implement a series of practices that minimizes nutrient and energy flows, minimizes risk, enhanced crop diversity and biological pest control through the best use of natural and local resources. While organic agriculture is no longer a new phenomenon within the developed countries which is now commercially practiced in 120 countries on 31 million ha of certified crop land and pasture and 62 million ha of certified wild lands and a market value of 40 billion US dollars in 2006, it is considered new and interesting option for sustainable agriculture in developing countries because it offers a unique combination of low external inputs and technology, environmental conservation and input/output efficiency. In Nigeria, organized organic agriculture is still young despite the great natural potentials that are endowed in virtually all the agro-ecological regions of the country. A well designed policy on organic agriculture can address three crucial aspect of sustainable agricultural development: environmental health through sustainable use of natural resources within and outside the agro-ecosystem; rural development through employment and community empowerment; and income generation through diversification, value addition, marketing and trade. This paper intends to highlights the potentials or opportunities that exist in Nigeria that can be exploited and optimized for sustainable development through organic agriculture. Constraints and way forward are also highlighted for organic agriculture development in Nigeria.
\end{abstract}

Key words: Nigeria, organic agriculture, potentials, rural development and sustainable development

\section{Introduction}

Organic agriculture is a production system that sustains the healthy soils, ecosystems, biodiversity and the people [7]. It relies on ecological processes and nutrient cycles adapted to local conditions, rather than use of external inputs with adverse effects. Organic agriculture combines traditional knowledge, innovation and modern science to benefit the shared environment and promote fair relationships and a good quality of life for all involved [5]. It also allows farmers to convert low inputs and subsistence farms into more productive systems and increase their ability to take advantage of local available resources. Through efficient use of natural resources and biodiversity, and recycling of renewable resources, organic agriculture allows farmers, pastoralists and fishers to flourish in the absence of external agricultural inputs [4].

According to the latest FiBL-IFOAM survey on organic agriculture, worldwide, (data as of end of 2010), organic agriculture covers a land area of 37 million ha in 160 countries with a total of 1.6 million producers worldwide. Thirty four percent of the world's organic producers are in Africa followed by Asia (29\%) and Europe (18\%). The countries with the most producers are India $(400,551)$, Uganda $(186,625)$ and Mexico $(128,862)$ [11]. The countries with the most organic land are Uganda ( 0.23 million ha), Tunisia $(0.18$ million ha) and Ethiopia (0.14 million ha). The majority of certified organic produced in Africa is destined for export to European Union, America and China where the market exist for organic produce. In Uganda, the export value for organic products was 42 million Dollars in 2010/2011 and in Ethiopia it was 33.9 million Dollars in 2010.

In Nigeria, the development of organic agriculture is still young with less than six years of experience. In 2007, Nigeria had 3,154 ha under organic agriculture of which 59 ha were fully converted [10] and are managed by few farmers and NGO's with little government involvement. However, [11] reported that in 2010, Nigeria land increase to 11,979 ha with 517 producers. This is not to say that the potentials for the development of organic agriculture are not abundant but rather much attention was given to conventional agriculture than organic agriculture. 
Organic agriculture is governed by a detailed standards and list of allowed and prohibited substances. In addition, the organic organization (IFOAM) has adopted four overriding principles for organic agriculture upon which organic systems is built which include principle of health-organic agriculture should sustain and enhance the health of soil, plant, animals and human; principle of ecology- organic agriculture should be based on living ecology systems and cycles, work with them, emulate them and help sustain them; principle of fairness- organic agriculture should build on relationships that ensure fairness with regard to the common environment and life opportunities; and principle of care- organic agriculture should be managed in a precautionary and responsible manner to protect the health and well being of current and future generations and the environment.

Organic agriculture is considered an interesting option for sustainable agricultural development in developing countries because it offers a unique combination of low external input technology, environmental conservation and input/output efficiency. NGO's and farmers are increasingly adopting organic agriculture techniques as a method of improving productivity and food security. Although there are numerous projects on the benefits on sustainable organic agriculture for farmers, environment and government in developing countries, scientifically solid information on organic agriculture remain scarce [3]. The benefit of organic agriculture to the farmer ranges from food security, rural employment and development, poverty reduction to improve livelihood to enhance productivity of poor rural communities [6]. Sustainable food security through organic agriculture therefore, enhance the attainment of Millenium Development Goal 1 on eradicating extreme hunger and poverty, goal 7 on environmental sustainability and goal 8 on partnerships.

In view of the above attendant benefits derived from organic agriculture for sustainable economy, rural and environmental development, the objective of this paper is to scrutinize the existing opportunities for organic agriculture in Nigeria with a view to harnessing them to achieve sustainable development.

\subsection{Organic agriculture in Nigeria}

\section{Conceptual Frame Work}

Unlike other African countries like Uganda, Ethiopia, Kenya and Tanzania, Nigeria is yet to develop its potentials in terms of organic agriculture, even though it is an agrarian country with track records of been world leading producer of some crops at one time or the other. Organic agriculture in an organized manner is still young in the country with less than six years of experience. [10 and 11] reported that, Nigeria only cultivate 3,154 ha and 11,979 ha in 2007 and 2010 respectively (TABLE 1). The practitioners are mostly few farmers and some NGO's that are involved and a certified farm in Nigeria currently sells its organic lemongrass tea, turmeric and other produce to the local market, a situation many regard as under-maximization of the premium benefits in organic agriculture [7].

TABLE 1 West African Countries with known areas of land under organic agriculture systems in 2007 and 2010

\begin{tabular}{|l|l|l|l|l|}
\hline \multicolumn{3}{|c}{2007} & \multicolumn{2}{c|}{2010} \\
\hline Countries & Land (ha) & $\begin{array}{l}\text { Number } \\
\text { producers }\end{array}$ & of & Land (ha) \\
\hline Benin & 1,488 & 2,354 & 1,167 & 1,992 \\
\hline Burkina Faso & 7,267 & 5,808 & 13,802 & 14,026 \\
\hline Ghana & 2,4449 & 3,900 & 12,635 & 2,327 \\
\hline Guinea Bissau & 5,600 & 401 & No data & No data \\
\hline Ivory coast & 943 & No data & 18,133 & 735 \\
\hline Mali & 3,402 & 7,526 & 15,199 & 27,711 \\
\hline Niger & 131 & No data & 48 & 1 \\
\hline Nigeria & 3,154 & No data & 11,979 & $517(2008)$ \\
\hline Senegal & 1,589 & 1,306 & 28,175 & $22,755(2009 / 2010)$ \\
\hline Togo & 2,545 & 3,409 & 3,618 \\
\hline
\end{tabular}

In spite of the low level of activities in the organic agriculture in Nigeria, it has great strengths that can be exploited for its accelerated development. [7] reported that at the moment, there are some organizations and stakeholders that are involved in networking, training, research and development of organic agriculture. These main stakeholders are:

Dara/Eurobridge Farm, which is the known pioneer organic farm in Nigeria that produces lemongrass, turmeric, ginger, plantain and medicinal herbs.

Organic Agriculture Project in Tertiary Institutions in Nigeria (OAPTIN), which organized a pioneering network in 2004. Its activities focus on capacity building and networking of academics in organic agriculture. 
Olusegun Obasanjo Centre for Organic Agriculture Research and Development (OOCORD), which was established in 2007 and is the first of its kind in Nigeria. It focuses on research and development in organic agriculture.

Nigerian Organic Agriculture Network (NOAN), which was formed as an initiative of OOCORD and designated to be an umbrella body for organic agriculture activities in Nigeria in August 2008. Its function is to network organic agriculture organizations in Nigeria.

Organic Farmers Association of Nigeria, Organic Fertilizer Association of Nigeria, "Nigeria Go Organic", "Ibadan Go Organic", are other organic stakeholders in the country.

Conferences and seminars were also held in promoting organic agricultural practice in Nigeria such as National conferences of organic agriculture from 2005-date and the first West African summit on organic agriculture which was held in University of Ibadan, Nigeria in 2012. Similarly, organic agriculture projects in tertiary institution in Nigeria organized summer programme on organic agriculture in 2010 and 2011 to train farmers, researchers and other interested groups. This activities rekindled hope of farmers and this new system of agriculture is gaining wide acceptability since the benefits are enormous. The recent pronouncement by the African Union to assist in the development of organic agriculture in the continent, of which Nigeria is a front runner, will help in boosting organic agriculture.

\section{Methodology}

The source of the information for this paper was secondary information. These informations were gathered from literature, journals, conference proceedings, organic organization bulletins and other supporting institutions. Personal observations and experience was also applied.

\subsection{Nigerian potentials for organic agriculture}

\section{Result and Discussion}

Nigeria, as any other developing country in Africa that is advanced in organic agriculture, is endowed with lots of natural and human resources that can be harnessed on a comparative advantage to produce agricultural crops organically to meet organic standards. The advantages and/or potentials use in conventional agriculture can be used in this new sector of agriculture to increase yield of crops, income and boost the economy and sustain the environment for continuous future production.

A review by [1] calculated average yield losses under organic for developed countries of $0-20 \%$ and, and in the case of developing countries, an increase of yield or hardly any yield reduction. In low external inputs systems, and especially in arid and semi- arid areas where most of the food insecure live, organic yields generally improve up to $180 \%$ [2 and 8]. Higher yields in low input systems are mainly achieved by the application of manure from integrated livestock production, composting and diversification. In humid areas where traditionally less livestock is integrated into the farming systems and little or no manure is available, organic yields depends on the availability of other organic nitrogen source. Nigeria being a developing country which has arid, semi-arid and humid climate fit into the above findings and could double its yield organically due to the favourable conditions existing in all the agro-ecological zones. Also the geographical location of the country is the best blessing from nature which provides the potentials for exploring virgin and untapped natural environment suitable for organic agriculture. The climate in the mountainous and plateau provide comparative advantage for the production of temperate crops which can be harnessed organically to increase yield of crops. The abundant natural resource in the country is another potential at the disposal of Nigeria to explore to develop organic agriculture apart from climate. Water, land and natural forest and grassland play a functional role in any agricultural production. Even though the soil in the northern part of the country are low in nutrients and/or organic matter, the adoption of the principle of recycling and crop rotation in organic agriculture could help in restoring the nutrient to enhance production. Total cultivable land in Nigeria is estimated at 61 million ha, which is $66 \%$ of the total area of the country. In 2002, the cultivated area was 33 million ha, of which arable covers 30.2 million ha [4]. This shows that the country has untapped land resources of about 28 million ha which can be harnessed for sustainable organic agriculture. Similarly, there is abundant water resources which include surface water from streams, rivers, lakes and dams $(96 \mathrm{~km} 3 /$ year) and the extensive groundwater which are located in eight recognized hydro geological areas together with local ground water in shallow alluvial (fadama) aquifers adjacent to major rivers $(59.51 \mathrm{~km} 3)$ [4]. This resource is not sufficiently tapped in the irrigation system of the country hence there is the need to exploit this natural resources in an efficient manner to necessitate increase food production towards sustainable development.

About $60-70 \%$ of Nigerian farmers are traditional rural farmers who by their nature of subsistence agriculture produce uncertified organic foods using localized and natural resources due to inability to secure synthetic inputs. Even though what they produce is considered non certified organic foods, their practices provide a good opportunity for easy conversion to organic practice. In Nigeria, these groups of farmers exist in every community and their number is a substantial one that can be use in improving organic agricultural 
development in the country since they are vulnerable to accept the principles of organic agriculture which is synonymous to their traditional system of production. In developing countries, the development of organic agriculture is mostly through conversion from conventional agriculture and this can be applicable to Nigeria context. The existing plantations, orchards and vegetable gardens in the country provide a good source of annual and perennial crops and can also withstand conversion to organic agriculture. The hydro agriculture practiced in the valleys along the river network under the River Basin Development Authority is another enormous potential that could be fully developed to achieve sustainable development through organic agriculture.

The forest and the grassland in Nigeria are home for wildlife which includes animals and plants that provide alternative sources of food for both human mad animals. These products of wild are found in large quantities and because they occur naturally, they can be harnessed, processed and consumes as organic foods. These wild produce that can be used organically are shear butter, gum Arabic, berries, nut, honey, snails, and mushrooms among others.

The introduction of organic agriculture into the curriculum of Nigerian universities, evolution of national organic agriculture network and the recent African Union's decision to support organic farming and their subsequent leadership in promoting and further developing framework/strategies for organic policies such as the Africa Ecological Organic Agriculture Initiative and the IFOAM-Africa Union conference that took place in Nairobi in 2011 is a good move by the government in promoting organic farming .

In spite of the several opportunities that abound in the country, Nigeria is yet to make its mark in organic agriculture in the region, continent and globally. This is due to several reasons among which lack of technical know-how is paramount.

\subsection{Challenges facing organic agricultural development in Nigeria}

The ever increasing challenges to agricultural productivity have necessitated application of alternative farming system in Africa. These challenges are exacerbated by inadequate institutional capacity, poor coordination and networking among the key players, inadequate financial resources and lack of or inaccessible innovation, all of which have left Africa farming systems underperforming and vulnerable. The Nigerian challenges may not be different from the above since most African countries share common characteristics. However, based on observation as well as review from past studies by [5 and 7], the main challenges facing the development of organic agriculture in Nigeria ranges from poor local marketing, low or no certification of organic produce, little or no information on organic agriculture and policies to safeguard it development, lack of appropriate inputs such as biofertilizers and pesticides, poor private sector involvement, lack of technical assistance, low level of interaction among organic networkers and with farmers to lack of funds to foster organic agriculture project among others.

\subsection{Way forward for the development of organic agriculture in Nigeria}

Challenges of organic agriculture in Nigeria are never permanent but rather stumbling block for the attainment of food security, rural development and environmental sustainability. Addressing these challenges require new institutional approach to development such as sustainable development and deployment of agricultural knowledge, science and technology which will draw on agro ecology, the science of applying ecological concepts and principles to the design and management of sustainable agro ecosystems. In Nigeria, the following interventions are needed from government, NGO's, private organization and international organization for proper growth and development of organic agriculture so as to achieve the MDG goal 1 (eradicate extreme hunger and poverty), goal 7 (ensure environmental sustainability) and goal 8 (develop a global partnership for development).

4.3.1 Education. In other to create awareness on organic agriculture in Nigeria, there is need to inculcate organic agriculture education in our school curriculum which will give foundation knowledge to young ones on the practice of organic agriculture and its benefits. Its inclusion in the universities should be boosted by research and government funding to sustain the programme. On the level of rural farmers, extension services should be enhanced and equipped to well inform farmers about organic agriculture and be encouraged to continue with their traditional way of farming and/or improve on it using organic principles and practices. Capacity building and training by government, research institutions, national and international organization for farmers should be encouraged.

4.3.2 Administration and policies. The recent endorsement of support for organic agriculture by African Union and subsequent developing framework/strategies for organic farming should be implemented on national and local level in each country of the continent and also backed by friendly and favourable policies. In line with this, government should provide or encourage the production of organic inputs such as biofertilizers and 
biopesticides to the farmers in subsidized rates, provide or approved certification agency that would promote certification of farms and marketing of organic foods internally and externally.

4.3.3 Marketing. The Nigeria market is a priced market which does not support premium price for organic produces as such farmers income cannot appreciate to compensate for the much labour required in organic farming. There should be organized standard sales outlets for organic products to bring producers closer to potential buyers and consumers should be well informed on the health values of organic through advertisement and other means. Regulations and quality control measures should be developed and strictly followed to conform to international standards to attract foreign trade.

4.3.4 Funding. Organic agriculture is labour intensive especially in the conversion period from conventional agriculture to organic agriculture. This will require farmers to pay for labour. To encourage the farmer, government should provide funds inform of loans and/or provide guarantee to farmers in commercial banks to obtain loans to increase their production. National and international organizations that encourage the development of organic agriculture for sustainable development should also provide funds to developing countries like Nigeria so that it can achieve the Millenium Development Goals.

4.3.5 Cooperation. The East African countries were able to increase their organic agricultural activities through cooperation among organic practitioners and this leads to export of organic produces which contributed to the domestic product of the countries involved [7]. Cooperation and integration brings about sharing of ideas, technology and strategy to develop individual countries involved in it. Nigeria, as a front runner in regional, continental and international affairs should integrate with those countries that are developed in organic agriculture so that the nascent organic agriculture can develop to full capacity for sustainable development.

\section{Conclusion}

Organic agriculture might not seem to be the answer to poverty but it is a feasible option for sustainable agriculture, rural development, provides fair return from labour and employment, develops the economy and sustains the environment for future production, hence leads to sustainable development in a nation.

\section{References}

[1]. O. A. Olugbenga, Organic agriculture and fair trade in West Africa, in Lim, L. C., Sue, E. and Nadia El-Hage, S. (eds.), Climate Change And food system resilience in Sub Saharan Africa.( F.A.O., 2011) 324-345.

[2]. International Federation of Organic Agriculture Movement, Network building for lobbying in Africa. Compiled by Souleymane Bassoum, René Tokannou and Nguji Mutura. (IFOAM, Bonn 2004).

[3]. Food and Agricultural Organisation, Water profile of Nigeria, in Jim Kundell (ed.) Encyclopedia of earth. (www.eoearth.org/article/water profile of Nigeria 2008).

[4]. H. Willer, and L. Kilcher, (eds.), The world of organic agriculture - Statistics and emerging trends 2012. Research Institute Organic Agriculture (FiBL),Frick and International Federation of Organic Agriculture (IFOAM Bonn, 2012).

[5]. H. Willer, and L. Kilcher, (eds.), The world of organic agriculture - Statistics and emerging trends 2009. Research Institute of Organic Agriculture (FiBL), Frick and International Federation of Organic Agriculture (IFOAM Bonn, 2009).

[6]. Z. Christine, and K. Lukas, Organic agriculture and food availability. (OFS Italy, 2007).

[7]. S., Nadia El-Hage, Organic agriculture and food security. (OFS Italy, 2007).

[8]. C., J. Badgley, E. Moghtader, E. Quintero, M. J. Zakem, K. Chappell, A. Aviles-Vaquez, Samulon, and I. Perfecto, Organic agriculture and the global food supply. Renewable Agriculture and Food Systems, 22, 2007, 86-108.

[9]. D. Blaise, Yield, bool distribution and fibre quality of hybrid cotton as influenced by organic and modern methods of distribution. Journal of Agronomy and Crop Science, 1992, 2006, 248-256.

[10]. J. Pretty, Lessons from certified and non-certified organic projects in developing countries, in El-Hage Scialabba N, Hattam C (eds), Organic agriculture, environment and food security. (FAO Rome, 2002) 139-162. 